\title{
Knowledge, Attitude, Practice and its Impact on Acetylcholine Esterase Level among Organophosphate Pesticide Applicators in South India
}

\author{
S. Jothi Lakshmi, Saranya Jaisankar and Krishnendu Mukhopadhyay* \\ Department of Environmental Health Engineering, Sri Ramachandra Institute of Higher Education and Research \\ (Deemed to be University), Porur, Chennai -600116, Tamil Nadu, India; jothilakshmipest25@gmail.com, \\ saranjaisankar@gmail.com, krishnendu@ehe.org.in
}

\begin{abstract}
Aim: To assess knowledge, attitude, practice and its impact on acetyl cholinesterase (AChE) level among 100 male Organophosphate pesticide applicators in South India. Methods/Statistical Analysis: A cross sectional study was performed among pesticide applicators in Theni district, Tamil Nadu. They were interviewed using a standard questionnaire on knowledge, attitude and practice. Blood samples were collected for serum AChE level. The results were analyzed using $R$ studio. Pearson correlation coefficient was used to determine relationships between variables. The $P$ value uses lower than 0.05 were considered statistically significant. Findings: Applicators reported high levels of knowledge on the name of the pesticide used in the agriculture field. The common symptoms felt by the applicators include eye and skin irritation and headache. Regarding Personal Protective Equipment (PPE) long pants and long sleeved shirt (78\%) were considered as most effective tool in controlling pesticide exposure. About $98 \%$ of the respondents were strongly agreed that pesticides are harmful to human health and environment and expensive chemicals are effective to control pest better than the cheaper chemicals. Blood results showed that $20 \%$ of participants' AChE levels were normal and remaining $80 \%$ of the participants' had an abnormal AChE levels. Knowledge was statistically significant with acetylcholine esterase level among organophosphate pesticide applicators. Conclusions: Knowledge shows a significant correlation with the AChE level. The applicators' AChE levels were found to be lower than the normal standard because of their pesticide exposure.
\end{abstract}

Keywords: Acetyl Cholinesterase (AChE), Attitude and Practice of Pesticide Use, Knowledge, Organophosphate Pesticides, Personal Protective Equipment's, Pesticide Applicators

\section{Introduction}

Agriculture plays a very prominent role in the maintenance of a healthy socio-economic status of India $\stackrel{1}{*}$. India ranked second in farm output and tenth in the pesticide consumption worldwide as its total consumption amounts to about 500 million tonnes (Economic Survey 2015-16). Agriculture sector is still remained back bone of the Indian economy. Nearly $58 \%$ of the rural households rely on agriculture as their principal means of livelihood.

Fertilizers and pesticide use are thought to be necessary to increase the yields in agriculture ${ }^{2}$. Pesticides are used by farm workers in order to protect their crops from insects, fungi and other organisms. It plays a crucial role in inhibiting pests that carry diseases to the crops $^{3}$. In recent times, greater concern has been placed on the impact of pesticides on public health and environment. Globally, information was available in the past few years about the adverse effects of pesticides on humans and the environment ${ }^{4}$. However, pesticide poisoning has been found to be significant problem in India. The World Health Organization (WHO) and the United Nations Environment programme estimate pesticide poisoning rates at 2-3 per minute, with a mortality of 20,000 workers

${ }^{*}$ Author for correspondence 
every year, due to exposure of pesticides and the majority being in developing countries 5 .

Organo-Phosphorus (OP) compounds cause most of the self-poisoning deaths in Southern India ${ }^{6}$ and it may be due to easy availability and low cost of organophosphate pesticides. The mortality of OP poisoning is very high in rural India, where poisoning is very severe due to lack of medical management ${ }^{7}$. Organophosphate pesticides mainly inhibit the carboxyl ester hydrolases, particularly AChE being one of the markers of oxidative stress in workers exposed to these substances ${ }^{8}$.

The activity of acetylcholine esterase is reduced to a greater extent due to exposure of organophosphates. Adherence to ineffective safety measures increases the potential risk of exposure to pesticides ${ }^{9}$. A single or repeated exposure to $\mathrm{AChE}$ inhibitors results in the build-up of acetylcholine in the synaptic cleft, and cause muscarinic and nicotinic receptors throughout the body, thereby exacerbating toxic effects such as nausea, bronchoconstriction, sialorrhea, hypertension and tremor, and affecting the central nervous system ${ }^{10}$.

Because of the limited studies in South India about the impact of Knowledge, Attitude and Practice (KAP) on AChE level due to pesticide exposure among applicators, it is hypothesized that pesticide applicators in the study area lack knowledge and follow improper usage of pesticide. The aim of the study is to assess Knowledge, Attitude, Practice and its impact on acetylcholine esterase level among organophosphate pesticide applicators in South India with the following objectives:

1. To assess knowledge, attitude and practice among applicators who use organophosphate pesticide in agricultural fields.

2. To determine the serum AChE levels in a subset of the sample population.

3. To find out association between KAP and AChE level among applicators.

\section{Materials and Methods}

\subsection{The Study Area}

A cross sectional study was conducted with a sample size of 100 and the study was carried out on the agricultural field among organophosphate pesticide applicators in 15 rural areas in Theni district of Tamil Nadu, India.
The study was conducted from March to May 2018. Male farm- pesticide applicators were the study subjects. The applicators were selected by convenient sampling; they practiced pesticide application in the area. These applicators engaged themselves in mixing the pesticides and loading them in containers and also spraying the mixture into crops

\subsection{Study Tools}

The farmers were interviewed based on the standardized questionnaire. The questionnaire consisted of following five parts: 1. General Information, 2. Personal Information, 3. Socioeconomic details, 4. Occupational details, and 5. Knowledge, Attitude and Practice among pesticide applicators. After getting the consent, the questionnaire was administered and blood samples were collected for AChE analysis.

\subsection{Human Blood Sample Collection}

About $3 \mathrm{~mL}$ of blood samples were collected in serum separator tubes from a random subset of participants $(n=50)$ who participated in the study. The collection protocol was approved by the Institutional Ethics committee of Sri Ramachandra University. Throughout the study period, strict code of practice was followed for sample collection, handling, storage, processing and archiving as outlined in the Ethical guidelines for Biomedical Research on Human Participants.

\subsubsection{Blood / Serum Analysis}

AChE assay using the Amplex Red acetylcholine esterase kit (Invitrogen Inc., USA; A12217) was done in the blood serum adhering to the manufacturer's instructions. To monitor the activity of AChE, indirectly, a sensitive flurogenic probe for $\mathrm{H}_{2} \mathrm{O}_{2}, 10$-acetyl-3,7-dihydroxyphenoxazine (Amplex Red) was added to the assay. The AChE converted the acetylcholine substrate to choline. This choline was oxidized by choline oxidase to betaine and $\mathrm{H}_{2} \mathrm{O}_{2}$. In the presence of horseradish peroxidise, the $\mathrm{H}_{2} \mathrm{O}_{2}$ obtained reacted with Amplex Red in a 1:1 stoichiometry thereby producing a highly fluorescent product namely resorufin. The excitation range of the fluorescence was at $545 \mathrm{~nm}$ and the emission was at $590 \mathrm{~nm}$. Technical triplicates were conducted. The reference values obtained were $3334-7031 \mathrm{mU} / \mathrm{L}$ for males and 2504- $6297 \mathrm{mU} / \mathrm{L}$ for females. 


\subsubsection{Statistical Analysis}

MS-Excel spread sheet was used to enter the data and appropriate statistical procedures (AVOVA and Pearson correlation coefficient) were employed for the analysis of the data. Pearson correlation coefficient was used to determine relationship between the variables. The specific variables were expressed in frequencies and percentages whereas continuous variables were expressed in mean \pm $\mathrm{SD}$. The $\mathrm{P}$ value, less than 0.05 was regarded as statistically significant.

\section{Results and Discussion}

\subsection{Results}

The demographic features of the 102 pesticide applicators are given in Table 1 . The ages of participants ranged from 30 to 65 years old, with an average age of 45 years.

Table 1. Demographic characteristics of the sample

\begin{tabular}{|c|c|}
\hline Demographic feature & N (\%) \\
\hline \multicolumn{2}{|l|}{ Age } \\
\hline $18-29$ & $\begin{array}{l}2 \\
(1.90)\end{array}$ \\
\hline $30-49$ & $70(68.62)$ \\
\hline$>50$ & $30(29.41)$ \\
\hline \multicolumn{2}{|l|}{ Education } \\
\hline Profession or honour & $19(18.62)$ \\
\hline Graduate or Post graduate & $14(13.72)$ \\
\hline $\begin{array}{l}\text { Intermediate or post high } \\
\text { school diploma }\end{array}$ & $45(44.11)$ \\
\hline High school certificate & $18(17.64)$ \\
\hline Middle school certificate & $\begin{array}{l}3 \\
(2.94)\end{array}$ \\
\hline Primary school certificate & $\begin{array}{l}3 \\
(2.94)\end{array}$ \\
\hline Illiterate & $\begin{array}{l}0 \\
(0)\end{array}$ \\
\hline \multicolumn{2}{|l|}{ Family Income Per Month } \\
\hline $9,249-13,873$ & $82(80.39)$ \\
\hline $5,574-9,248$ & $20(19.60)$ \\
\hline \multicolumn{2}{|l|}{ Smoking habit } \\
\hline Smokers & $50(49.02)$ \\
\hline Non-smokers & $52(50.98)$ \\
\hline Alcohol & \\
\hline
\end{tabular}

\begin{tabular}{|l|l|}
\hline Yes & $67(65.68)$ \\
\hline No & $35(34.31)$ \\
\hline Tobacco & \\
\hline Yes & $\begin{array}{l}9 \\
(8.82)\end{array}$ \\
\hline No & $93(91.17)$ \\
\hline Year of Pesticide use (years) & \\
\hline $0-5$ & $12(11.76)$ \\
\hline $6-10$ & $16(15.68)$ \\
\hline$>10$ & $74(72.54)$ \\
\hline Work shift & \\
\hline Half day (5-8 hours) & $102(100)$ \\
\hline
\end{tabular}

\subsubsection{Knowledge Regarding Pesticides among the Applicators}

It has been found that $94 \%$ of the respondents were familiar with the name of pesticide used in agriculture and 89 $\%$ of the farmers had a general knowledge of health risks associated with the use of pesticides. Most of the respondents believed that health risk due to handling of pesticide was severe (Table 2).

Table 2. Shows the applicators' replies to questions about their knowledge of pesticide

\begin{tabular}{|c|c|c|}
\hline \multirow{2}{*}{ Knowledge statements } & Yes & No \\
\hline & $\mathrm{N}(\%)$ & $\mathrm{N}(\%)$ \\
\hline $\begin{array}{l}\text { Do you know the name of pesticide } \\
\text { used? }\end{array}$ & \begin{tabular}{|l|}
96 \\
$(94.11)$
\end{tabular} & $\begin{array}{l}6 \\
(5.89)\end{array}$ \\
\hline $\begin{array}{l}\text { Do you have a general knowledge of } \\
\text { health risks associated with pesticide } \\
\text { use? }\end{array}$ & \begin{tabular}{|l|l}
91 \\
$(89.21)$
\end{tabular} & \begin{tabular}{|l|}
11 \\
$(10.79)$
\end{tabular} \\
\hline $\begin{array}{l}\text { Are you aware of the severity of } \\
\text { pesticides on your health? }\end{array}$ & \begin{tabular}{|l|}
92 \\
$(90.19)$
\end{tabular} & $\begin{array}{l}10 \\
(9.81)\end{array}$ \\
\hline \multicolumn{3}{|l|}{$\begin{array}{l}\text { Are you aware of the fact that } \\
\text { pesticides can enter your body } \\
\text { through the following ways? }\end{array}$} \\
\hline a) Skin & \begin{tabular}{|l|}
102 \\
$(100)$
\end{tabular} & \begin{tabular}{|l|}
0 \\
$(0)$
\end{tabular} \\
\hline b) Mouth & \begin{tabular}{|l|}
101 \\
$(99.01)$
\end{tabular} & $\begin{array}{l}1 \\
(0.99) \\
\end{array}$ \\
\hline c) Nose & \begin{tabular}{|l|l|}
100 \\
$(98.03)$ \\
\end{tabular} & \begin{tabular}{|l|}
2 \\
$(1.97)$ \\
\end{tabular} \\
\hline d) Eyes & $\begin{array}{l}100 \\
(98.03)\end{array}$ & $\begin{array}{l}2 \\
(1.97)\end{array}$ \\
\hline $\begin{array}{l}\text { Do you know that the following } \\
\text { symptoms are caused by pesticide } \\
\text { exposure? }\end{array}$ & & \\
\hline
\end{tabular}




\begin{tabular}{|l|l|l|}
\hline a) Headaches & $\begin{array}{l}80 \\
(78.43)\end{array}$ & $\begin{array}{l}22 \\
(21.57)\end{array}$ \\
\hline b) Eye irritation & $\begin{array}{l}91 \\
(89.21)\end{array}$ & $\begin{array}{l}11 \\
(10.79)\end{array}$ \\
\hline c) Nausea and vomiting & $\begin{array}{l}17 \\
(16.66)\end{array}$ & $\begin{array}{l}85 \\
(83.34)\end{array}$ \\
\hline d) Dizziness and Muscle Weakness & $\begin{array}{l}6 \\
(5.88)\end{array}$ & $\begin{array}{l}96 \\
(94.12)\end{array}$ \\
\hline e) Difficulty in breathing & $\begin{array}{l}4 \\
(3.92)\end{array}$ & $\begin{array}{l}98 \\
(96.08)\end{array}$ \\
\hline f) Diarrhea & $\begin{array}{l}2 \\
(1.96)\end{array}$ & $\begin{array}{l}100 \\
(98.04)\end{array}$ \\
\hline g) Chest pain & $\begin{array}{l}5 \\
(4.90)\end{array}$ & $\begin{array}{l}97 \\
(95.10)\end{array}$ \\
\hline h) Skin irritation & 90 & 12 \\
$(88.23)$ & $(11.77)$ \\
\hline $\begin{array}{l}\text { Do you think that it is important to } \\
\text { follow the protective measures? }\end{array}$ & $\begin{array}{l}99 \\
(97.05)\end{array}$ & $\begin{array}{l}3 \\
(2.95)\end{array}$ \\
\hline $\begin{array}{l}\text { Which of the following protective } \\
\text { clothing against pesticide exposure, do } \\
\text { you think is most effective? }\end{array}$ & \multicolumn{2}{|l}{} \\
\hline a) Masks & $\begin{array}{l}27 \\
(26.47)\end{array}$ & $\begin{array}{l}75 \\
(73.53)\end{array}$ \\
\hline b) Gloves & $\begin{array}{l}3 \\
(2.94)\end{array}$ & $\begin{array}{l}99 \\
(97.06)\end{array}$ \\
\hline c) Long pants and long sleeved shirt & $\begin{array}{l}80 \\
(78.43)\end{array}$ & $\begin{array}{l}22 \\
(21.57)\end{array}$ \\
\hline d) Half pants and half sleeved shirt & $\begin{array}{l}22 \\
(21.56)\end{array}$ & $\begin{array}{l}80 \\
(78.44)\end{array}$ \\
\hline e) Towel/Kerchief & $\begin{array}{l}43 \\
(42.15)\end{array}$ & $\begin{array}{l}59 \\
(57.85)\end{array}$ \\
\hline
\end{tabular}

The farmers were able to list out the common routes of pesticide exposure as skin, eyes, nose and mouth. They were aware of the symptoms like eye irritation, headache, skin irritation and nausea and vomiting (Figure 1). Ninety- seven percent of the farmers believed that it is important to use protective measures. Regarding Personal Protective Equipment (PPE), long pants and long sleeved shirt were considered as the most effective tool in controlling pesticide exposure. Some of the farmers believed that using towel/ kerchief would work well against the entry of pesticides through nose or head. A very few participants expressed their belief that pesticide exposure could be prevented by using gloves (Figure 2).

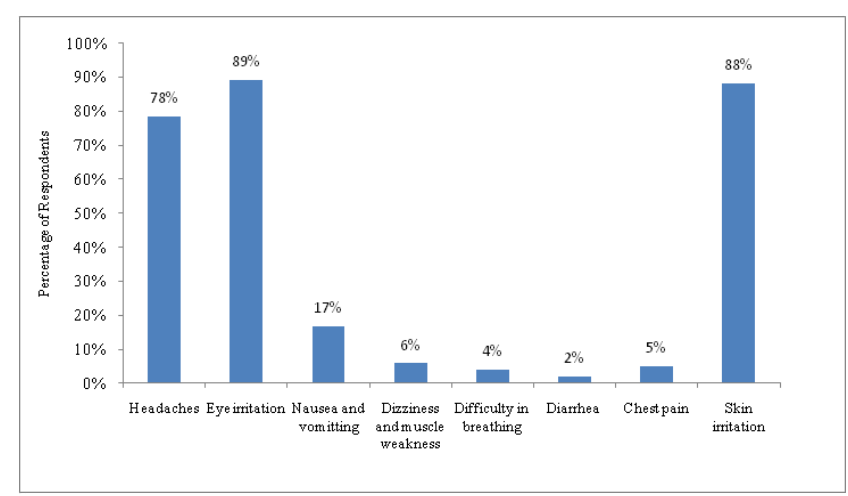

Figure 1. Shows the knowledge about the symptoms caused by the pesticide exposure.

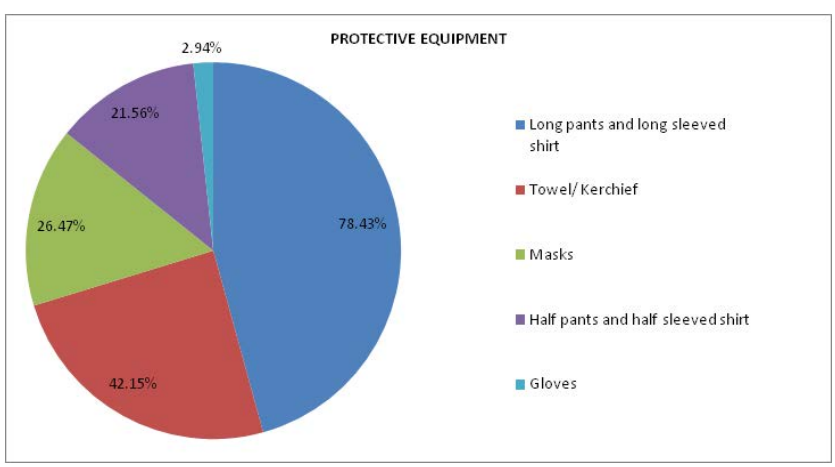

Figure 2. Shows the percentage of protective equipment.

\subsubsection{Attitudes Regarding Pesticides among the Applicators}

Most of the farmers (95.09\%) strongly disagreed to pesticides pass only through ingestion route into the body. Participants disagreed on the factor; pesticides are harmful to insects only, not harmful to human health. The majority of farmers believed that using tool to mix the pesticides was safer than using hand (Table 3 ).

\subsubsection{Practice Regarding Pesticides among the Applicators}

Before spraying of pesticides, the farmers reported that they bought pesticides through neighbours' recommendation and through agricultural officers or pesticide shop keepers. More than half of respondents never wore gloves and masks while mixing the pesticides (Table 4). Wind plays a major role in pesticide spraying. Most of the applicators' said, they sprayed pesticide according to the windward direction, so as to reduce the direct expo- 
Table 3. Shows the applicators' response to questions regarding their attitudes towards pesticides

\begin{tabular}{|l|l|l|l|}
\hline \multirow{2}{*}{ Attitude statements } & $\begin{array}{l}\text { Strongly } \\
\text { Agree/ Agree }\end{array}$ & Neutral & $\begin{array}{l}\text { Strongly } \\
\text { Disagree/ } \\
\text { Disagree }\end{array}$ \\
\cline { 2 - 4 } & $\mathbf{N}(\%)$ & N (\%) & N (\%) \\
\hline $\begin{array}{l}\text { Pesticides can pass only through ingestion route into the } \\
\text { body }\end{array}$ & $\begin{array}{l}3 \\
(2.95)\end{array}$ & $\begin{array}{l}2 \\
(1.96)\end{array}$ & $\begin{array}{l}97 \\
(95.09)\end{array}$ \\
\hline $\begin{array}{l}\text { Pesticides are harmful to insects only, not harmful to } \\
\text { human health }\end{array}$ & $\begin{array}{l}4 \\
(3.92)\end{array}$ & $\begin{array}{l}5 \\
(4.90)\end{array}$ & $\begin{array}{l}93 \\
(91.18)\end{array}$ \\
\hline $\begin{array}{l}\text { Mixing of various pesticides will increase the effect and } \\
\text { has no disadvantages }\end{array}$ & $\begin{array}{l}26 \\
(25.49)\end{array}$ & $\begin{array}{l}30 \\
(29.41)\end{array}$ & $\begin{array}{l}46 \\
(45.10)\end{array}$ \\
\hline Using tool to mix the pesticides is safer than using hand & $\begin{array}{l}96 \\
(94.10)\end{array}$ & $\begin{array}{l}3 \\
(2.95)\end{array}$ & $\begin{array}{l}3 \\
(2.95)\end{array}$ \\
\hline $\begin{array}{l}\text { Use pesticides more than label recommendation may } \\
\text { increase the yield }\end{array}$ & $\begin{array}{l}34 \\
(33.33)\end{array}$ & $\begin{array}{l}21 \\
(20.59)\end{array}$ & $\begin{array}{l}47 \\
(46.08)\end{array}$ \\
\hline $\begin{array}{l}\text { Pesticides are harmful to human health and environment } \\
\text { (100) }\end{array}$ & $(98.04)$ & $\begin{array}{l}0 \\
(0)\end{array}$ & $\begin{array}{l}2 \\
(1.96)\end{array}$ \\
\hline $\begin{array}{l}\text { Expensive chemicals are effective to control pest better } \\
\text { than the cheaper chemicals }\end{array}$ & $\begin{array}{l}100 \\
(98.04)\end{array}$ & $\begin{array}{l}2 \\
(1.96)\end{array}$ & $\begin{array}{l}0 \\
(0)\end{array}$ \\
\hline
\end{tabular}

sure. $89.22 \%$ of respondents had never smoked or drank water or eaten while spraying pesticides. More than half of the farmers washed their hands and face with soap before they had their meal. Approximately $41.18 \%$ of the respondents took shower immediately after they sprayed pesticides.

\subsubsection{Serum Acetylcholinesterase Level among Pesticide Applicators}

In this study, pesticide applicators were included to find their levels of serum acetyl cholinesterase (AChE). Blood results showed that $20 \%$ of participants' AChE levels were normal and $80 \%$ of the participants' had an abnormal AChE level. The reference value for men was between 3334 and $7031 \mathrm{mU} / \mathrm{L}^{\underline{11}}$. Of the 50 study participants, 40 of them had lower (abnormal) acetylcholine esterase level and only 10 had normal AChE level (Figure 3).

\subsubsection{Relationship between Knowledge, Attitude, Practice and AChE Level}

The study showed that knowledge was statistically significant with acetylcholine esterase level among organophosphate pesticide applicators $(\mathrm{R}=0.4768)$. On the other hand, the relationship between attitude, practice and acetylcholine esterase level were not statistically significant (Table 5).

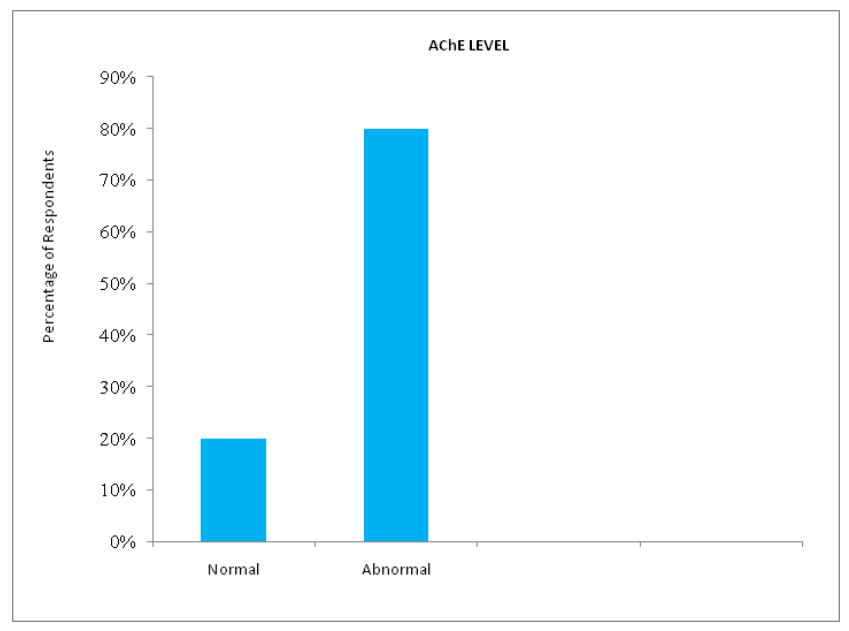

Figure 3. Shows the Acetylcholinesterase level among applicators.

\subsection{Discussion}

The average age of the applicators was 45 years. Their level of education was predominantly post high school diploma. The majority of the respondents were alcoholic and half of them were smokers. About three-fourth of the applicators had worked for $>10$ years. The applicators worked on full-day shift which indicated that pesticide spraying was performed from morning to evening (5-8 hours) of the day.

Approximately $90 \%$ of the respondents showed the knowledge about the name of the pesticides and had a 
Table 4. Shows the practice among pesticide applicators

\begin{tabular}{|c|c|c|c|c|}
\hline Practice Items & Usual & Some-times & Rare & Never \\
\hline Before Spraying & $\mathrm{N}(\%)$ & $\mathrm{N}(\%)$ & $\mathrm{N}(\%)$ & $\mathrm{N}(\%)$ \\
\hline $\begin{array}{l}\text { Do you select pesticide by neighbours' recommenda-tion, } \\
\text { Watching advertise-ment, looking at the price or a shop? }\end{array}$ & $0(0)$ & $19(18.64)$ & $34(33.33)$ & $49(48.03)$ \\
\hline Do you read the label to follow the instructions before use? & $\begin{array}{l}38 \\
(37.26) \\
\end{array}$ & $\begin{array}{l}52 \\
(50.98) \\
\end{array}$ & $\begin{array}{l}11 \\
(10.78)\end{array}$ & $\begin{array}{l}1 \\
(0.98) \\
\end{array}$ \\
\hline $\begin{array}{l}\text { Do you check the equip-ments and material before using/ } \\
\text { spraying? }\end{array}$ & $\begin{array}{l}60 \\
(58.82)\end{array}$ & $\begin{array}{l}40 \\
(39.22)\end{array}$ & $\begin{array}{l}2 \\
(1.96)\end{array}$ & $\begin{array}{l}0 \\
(0)\end{array}$ \\
\hline $\begin{array}{l}\text { Do you prohibit human and animal entry from spraying } \\
\text { area? }\end{array}$ & $\begin{array}{l}47 \\
(46.09)\end{array}$ & $\begin{array}{l}39 \\
(38.22)\end{array}$ & $\begin{array}{l}16 \\
(15.69)\end{array}$ & $\begin{array}{l}0 \\
(0)\end{array}$ \\
\hline Do you wear gloves and mask while mixing the pesticides? & $\begin{array}{l}2 \\
(1.96)\end{array}$ & $\begin{array}{l}3 \\
(2.94)\end{array}$ & $\begin{array}{l}22 \\
(21.57)\end{array}$ & $\begin{array}{l}75 \\
(73.53)\end{array}$ \\
\hline \multicolumn{5}{|l|}{ While Spraying } \\
\hline Do you wear clothes fully during pesticide appli-cation? & $\begin{array}{l}16 \\
(15.69)\end{array}$ & $\begin{array}{l}49 \\
(48.03) \\
\end{array}$ & $\begin{array}{l}35 \\
(34.32) \\
\end{array}$ & $\begin{array}{l}2 \\
(1.96) \\
\end{array}$ \\
\hline Do you eat/ drink/ smoke during pesticide appli-cation? & $\begin{array}{l}1 \\
(0.98)\end{array}$ & $\begin{array}{l}2 \\
(1.96)\end{array}$ & $\begin{array}{l}8 \\
(7.84)\end{array}$ & $\begin{array}{l}91 \\
(89.22)\end{array}$ \\
\hline Do you spray pesticide while windy? & $\begin{array}{l}17 \\
(16.67) \\
\end{array}$ & $\begin{array}{l}62 \\
(60.78) \\
\end{array}$ & $\begin{array}{l}20 \\
(19.61)\end{array}$ & $\begin{array}{l}3 \\
(2.94) \\
\end{array}$ \\
\hline $\begin{array}{l}\text { Do you stand in the windward direction while spraying } \\
\text { without protective equipment? }\end{array}$ & $\begin{array}{l}3 \\
(2.94)\end{array}$ & $\begin{array}{l}5 \\
(4.91)\end{array}$ & $\begin{array}{l}38 \\
(37.25)\end{array}$ & $\begin{array}{l}56 \\
(54.90)\end{array}$ \\
\hline \multicolumn{5}{|l|}{ After Spraying } \\
\hline Do you burn or bury the empty pesticide containers? & $0(0)$ & $1(0.98)$ & $16(15.69)$ & $85(83.33)$ \\
\hline Do you wash clothes immediately after spraying? & $\begin{array}{ll}41 \\
(40.20)\end{array}$ & $\begin{array}{ll}38 \\
(37.26)\end{array}$ & $\begin{array}{ll}12 \\
(11.76)\end{array}$ & $\begin{array}{l}11 \\
(10.78) \\
\end{array}$ \\
\hline Do you store the remaining pesticides at home? & $\begin{array}{ll}7 \\
(6.87)\end{array}$ & $\begin{array}{ll}16 \\
(15.69)\end{array}$ & $\begin{array}{ll}40 \\
(39.21)\end{array}$ & $\begin{array}{ll}39 \\
(38.23)\end{array}$ \\
\hline $\begin{array}{l}\text { Do you wash your hands and face with soap before having } \\
\text { meal? }\end{array}$ & $\begin{array}{l}62 \\
(60.78)\end{array}$ & $\begin{array}{l}30 \\
(29.42)\end{array}$ & $\begin{array}{l}8 \\
(7.84) \\
\end{array}$ & $\begin{array}{l}2 \\
(1.96) \\
\end{array}$ \\
\hline Do you take a shower immediately after spray? & $\begin{array}{l}42 \\
(41.18)\end{array}$ & $\begin{array}{l}36 \\
(35.29)\end{array}$ & $\begin{array}{l}16 \\
(15.69)\end{array}$ & $\begin{array}{l}8 \\
(7.84)\end{array}$ \\
\hline
\end{tabular}

Table 5. Shows the correlation between knowledge, attitude, practice and a AChE level

\begin{tabular}{|l|l|l|l|}
\hline & N $(\%)$ & AChE level $($ mean \pm SD) & r value \\
\hline Knowledge & & & \\
\hline Low level knowledge & $5(10)$ & $2811.416 \pm 1242.976$ & \multirow{2}{*}{$0.4768^{\star}$} \\
\hline Moderate level knowledge & $27(54)$ & $2643.533 \pm 875.8718$ & \\
\hline High level knowledge & $18(36)$ & $2977.960 \pm 1051.905$ & \\
\hline Attitude & & & \multirow{2}{*}{0.0946} \\
\hline Concerned & $45(90)$ & $2747.491 \pm 1064.226$ & \\
\hline Not concerned & $5(10)$ & $3079.735 \pm 1242.976$ & \\
\hline Practice & & & \multirow{2}{*}{0.00528} \\
\hline Good practice & $10(20)$ & $2749.965 \pm 1046.959$ & \\
\hline Bad practice & $40(80)$ & $2788.403 \pm 1074.797$ & \\
\hline
\end{tabular}

${ }^{*}$ correlation is significant at 0.10 levels 
general awareness on the health risks related to the use of pesticides and awareness about its effect on human health. Similar findings were revealed in Puducherry study ${ }^{12}$. Almost all of the respondents believed that pesticides entered through mouth (ingestion), nose (inhalation), skin dermal (absorption) and eyes. This study observed the major symptoms felt by the applicators due to pesticide exposure which included skin irritation, headache, and eye irritation, followed by nausea and vomiting. Studies have found that the maximum absorption of pesticides is through skin. Eye irritation and headache were the commonest symptoms among the sprayers and the agricultural organophosphate dispersions play a significant role in the incidence of visual problems $s^{13-15}$.

The applicators felt that the protective measures are important. The results of this study showed the availability of a number of personal protective clothes, of which the long pants and long sleeved shirt are believed to be more effective compared to other clothing. Also, the applicators were concerned about the cost of the protective equipment and their financial status played a role in choosing the personal equipment. A similar study showed that high cost of personal protective equipment to have been the cause for its limited use $\mathrm{e}^{14}$. The applicators might not choose to wear such a gear (safety shoes, gloves and goggles) because they perceived that those items might create discomfort and would reduce their working efficiency.

Though the participants possessed a high level of knowledge for specific health outcome related to pesticide use, the participants felt that most of the farmers were physically healthy to handle the pesticides. Almost all participants believed that the pesticides could pass through all the routes. Approximately $98 \%$ of the respondents knew the harmful nature of pesticides to humans and the environment, which is similar to a study which showed that $93 \%$ of the males and females had accepted that pesticides were harmful to human health and livestock $\frac{16}{}$.

Regarding practice, approximately $90 \%$ of the respondents never ate or drank or smoked during pesticide spraying. Some of the applicators in this study hesitated to read the instructions because of their attitude towards pesticides and their heavy work. Few of the farmers could not read or understand the instructions written on the pesticide containers, which are mainly in English language other than their native language. The air current also plays a major role in pesticide spraying. Most of the applicators said, they would spray pesticide according to the windward direction, so that it would reduce the direct exposure. Attitude regarding spraying pesticides showed that the farmers sprayed pesticides in the direction of the wind 17 .

The study results showed that mixing and loading the pesticides into the containers using bare hands, without any personal protective equipment increased the exposure of pesticides to other parts of the body. Improper handling of pesticides by farmers increased their exposure to pesticides. Many applicators believed that washing their hands and the body using soap would wash away the pesticides from their body surfaces, but few of the applicators were not able to take bath immediately because of their continuous work in the land or due to inadequate facility in the working area. A study reported that less than half of the farmers used personal protective equipment while spraying pesticides and washed their hands, showered or laundered their clothes after spraying ${ }^{18}$.

A very few of the applicator said, that it was not a problem for them which suggested their lack of knowledge on the harmful nature of the chemicals. The majority of the applicators felt that careful handling of pesticides was more important and regular or/and proper usage of personal protective equipment would limit the risk of direct contact and inhalation exposure of pesticides. It is important to raise the awareness among the sprayers on the harmful nature of the chemicals and their attitudes and practices. Their experience in the field and their educational status could be the reason for not following safety precautions.

Farmer's attitudes and clothing practices were contradictory. Though the farmers believed that their work clothing would be effective in protecting them from exposure, for comfort they rolled up their long pants and long-sleeved shirts (protective gear) and mixed or sprayed the pesticides, thereby their protective gear became ineffective. The farmers wore the ineffective denim pants and

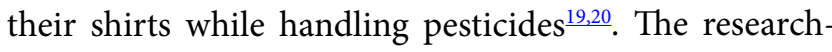
ers found a significant variation in the serum AChE level among the applicators. A study in Nepal by reported a variation in the erythrocyte acetylcholine esterase activity before and after pesticide application season?.

\section{Conclusion}

Farmers play an important role in the economy of a country. But they are considered as a weaker community in India. As evidenced in the study the applicators/ farmers' willingness towards the use of protective clothing 
and equipment were identified. Risky behaviour was also demonstrated by the farmers while or after performing pesticide activities including storing the remaining pesticides in the home, not wearing fully covered clothing during pesticide application, not taking shower immediately after pesticide application and failing to change the working clothes. The farmers were following the unsafe practices due to their lack of understanding of the safe practices involved while spraying pesticides and there was no formal or proper training/ education for them; usually they gained information from elders. Participants also expressed that they were not trained in the use of appropriate clothing while using pesticides. The study showed the applicator's AChE levels to be lower than the normal standards because of their knowledge regarding pesticide exposure. Knowledge showed a significant correlation with the AChE level but attitude and practice didn't show any significant correlation with the AChE level.

\subsection{Recommendations}

Based on the findings of this study, it is suggested to adopt appropriate policy and educational programmes that would increase the knowledge and awareness among the farmers about the pesticide toxicity and its health effects. Some farmers use PPEs but have been observed to be unaware of the way it should be used. This is important as inappropriate use of PPEs may increase the exposure levels resulting in unanticipated health effects. Training on pesticide spraying methods and wearing appropriate protection tools are the necessary fields that require immediate action. Policy makers should think about adequate health and safety education for this class of population either by conducting block-based training or through media on regular basis. It is equally important to encourage formers for 'organic way' of producing goods.

\subsection{Limitations}

The main limitation in this study was insufficient financial resources as it was self-funded study that had to complete within limited time period. Due to same limitation, smaller sample size had to consider which influenced not identifying significant acetylcholine esterase level.

\section{Acknowledgment}

The authors extend their deep sense of gratitude to all the study participants and the author acknowledge Mr.
Senthil Kumar Lab technician and healthcare workers and Ms. Meryn Selvanayagam Lecturer, Department of English, Sri Ramachandra Institute of Higher Education and Research, India.

\section{References}

1. Next Generation Indian Agriculture - Role of Crop Production Solutions. Federation of Indian Chambers of Commerce and Industry. Knowledge and strategic Partner. Tata Strategic Management Group; 2016. p. 1-56.

2. Vijay Kautilya D, Shruti P, Hegde, Khatija Begum, Prithika Chandra Shekaran. Knowledge, attitude and practice of pesticide safety measures among paddy farmers in South India, Indian Journal of Forensic and Community Medicine. 2017; 4(2):138-42.

3. Wasim Aktar Md, Sengupta D, Chowdhury A. Impact of pesticides use in agriculture: Their benefits and hazards, Interdisciplinary Toxicology. 2009; 2(1):1-12. https://doi. org/10.2478/v10102-009-0001-7. PMid: 21217838, PMCid: PMC2984095.

4. Ajayi OC. Socio-economic Assessment of Pesticide Use in Mali. Pesticide Policy Project; 2002. p. 1-69.

5. Lavanya Kumari P, Giridhar Reddy K. Knowledge and practices of safety use of pesticides among farm workers, IOSR Journal of Agriculture and Veterinary Science. 2013; 6(2):1-8. https://doi.org/10.9790/2380-0620108.

6. Srinivas Rao $\mathrm{CH}$, Venkateswarlu V, Surender T, Michael Eddleston, Nick A Buckley. Pesticide poisoning in South India - Opportunities for prevention and improved medical management, Tropical Medicine and International Health. 2005; 10(6):581-88. https://doi.org/10.1111/j.13653156.2005.01412.x. PMid: 15941422, PMCid: PMC1762001.

7. Ahmed SM, Das B, Nadeem A, Samal RK. Survival pattern in patients with acute organophosphate poisoning on mechanical ventilation: A retrospective intensive care unit-based study in a tertiary care teaching hospital, Indian Journal of Anesthesia. 2014; 58(1):11-7. https://doi. org/10.4103/0019-5049.126780. PMid: 24700893, PMCid: PMC3968644.

8. Taghavian F, Vaezi G, Abdollahi M, Malekirad AA. Comparative toxicological study between exposed and non - exposed farmers to organophosphate pesticides, Cell Journal. 2016; 18(1):89-96. PMid: 27054123, PMCid: PMC4819391.

9. Atreya K, Bajracharya RM, Sitaula B. Knowledge, attitude and practice of pesticide use and acetylcholinesterase depression among farm workers in Nepal, International Journal of Environmental Research and Public Health. 2012; 22(5):401-15. https://doi.org/10.1080/09603123.201 1.650154. PMid: 22273496. 
10. Colosio C, Tiramani M, Maroni M. Neurobehavioral effects of pesticides: State of the art, Neuro Toxicology. 2003; 24:577-91. https://doi.org/10.1016/S0161813X(03)00055-X.

11. Velmurugan et al, Gut microbial degration of organophosphate insecticides- induces glucose intolerance via gluconeogenesis, Genome Biology. 2017; 18(8).

12. Manoj Kumar Mohanty MD, Basanta Kumar Behera MD, Saubhagya Kumar Jena MD, S. Srikanth MD, C. Mogane, M. Phil, Soumya Samal DNB, Anugya Aparajita Behera M.Sc. Knowledge attitude and practice of pesticide use among agricultural workers in Puducherry, South India, Journal of Forensic and Legal Medicine. 2013; 20:1028-31. https:// doi.org/10.1016/j.jflm.2013.09.030. PMid: 24237813.

13. Yassin MM, AbuMourad TA, Safi JM. Knowledge, attitude, practice and toxicity symptoms associated with pesticide use among farm workers in the Gaza Strip, Occupational and Environmental Medicine. 2002; 59:387-94. https:// doi.org/10.1136/oem.59.6.387. PMid: 12040114, PMCid: PMC1740291.

14. Mekonnen Y, Agonafir T. Pesticide sprayer's knowledge, attitude and practice of agricultural farms of Ethiopia, Occupational Medicine (Lond). 2002; 52(6):311-15. https://doi.org/10.1093/occmed/52.6.311.
15. Dementi B. Ocular effects of organophosphates: A historical perspective of Saku disease, Journal of Applied Toxicology. 1994; 14(2):119-29. https://doi.org/10.1002/ jat.2550140214. PMid: 8027507.

16. Atreya K. Pesticide use knowledge and practices: A gender differences in Nepal. Alternative Development and Research Center (ADRC); 2007. PMCid: PMC2095672.

17. Pasiani JO, Torres P, Roniery Silva J, Diniz BZ, Caldas ED. Knowledge, practices and biomonitoring of farmers and residents exposed to pesticides in Brazil, International Journal of Environmental Research. 2012; 9:3051-68.

18. Norkaew S, Siriwongl W, Siripattanakul S, Robson M. Knowledge, Attitude and Practice (KAP) of using Personal Protective Equipment (PPE) for chilli growing farmers in Huarua sub - District Mueang district, Ubonrachathani province, Thailand, Journal of Health Research. 2010; 24(2):93-100.

19. Derafshi M, Black C, Agnew R. Knowledge, attitudes and clothing practices of Turkish Farmers, Environmental Management and Sustainable Development. 2017; 6(1).

20. Stone J, Padgitt S, Wintersteen W, Shelley M, Chisholm S. Iowa greenhouse applicators' perceptions and use of personal protective equipment, Journal of Environmental Health. 1994; 57:16-22. 